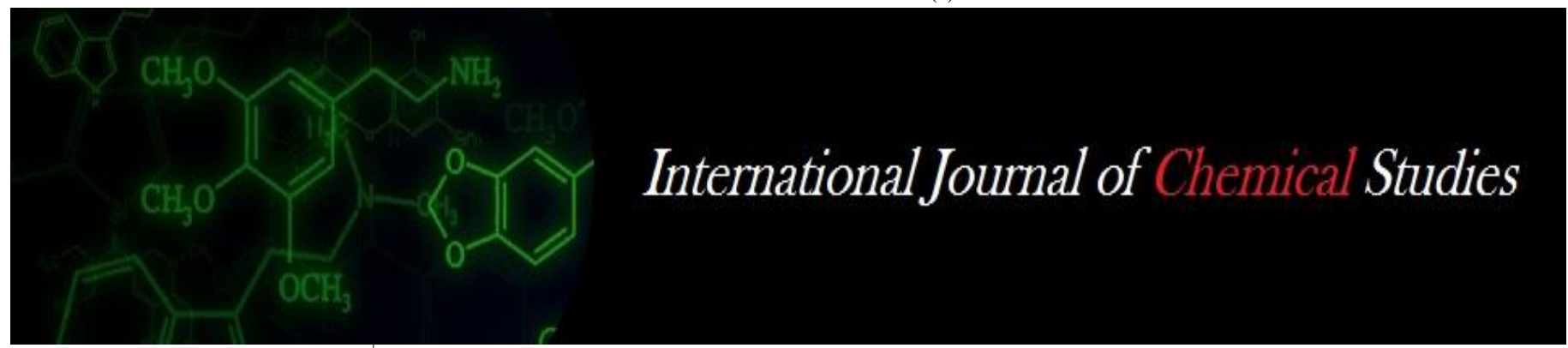

P-ISSN: 2349-8528

E-ISSN: 2321-4902

www.chemijournal.com

IJCS 2021; 9(1): 2507-2510

(C) 2021 IJCS

Received: 14-11-2020

Accepted: 23-12-2020

Dr. Vijaya Geetha V

Assistant Professor, Oilseeds

Research Station, TNAU,

Tindivanam, Tamil Nadu, India

PC Prabu

Assistant Professor, Oilseeds

Research Station, TNAU,

Tindivanam, Tamil Nadu, India

\section{S Thiruvarassan}

Assistant Professor, Oilseeds

Research Station, TNAU,

Tindivanam, Tamil Nadu, India

\section{Bhaskaran}

Professor and Head, Rice

Research Station, TNAU, Tirur,

Tamil Nadu, India
Corresponding Author: Dr. Vijaya Geetha V Assistant Professor, Oilseeds Research Station, TNAU, Tindivanam, Tamil Nadu, India

\section{Evaluation of single pod sowing in groundnut}

\author{
Dr. Vijaya Geetha V, PC Prabu, S Thiruvarassan and M Bhaskaran
}

DOI: https://doi.org/10.22271/chemi.2021.v9.i1ai.11606

\begin{abstract}
In groundnut, the coverage of area by a particular variety is very poor compared to cereals, this is mainly due to non-availability of quality seeds at the time of sowing. The formation of single pods is inevitable one. To utilize the single pods as such without decorticating, it can reduce shelling cost and meet out the demand of the crop at needy time. The present investigation has been formulated and conducted at Oilseeds Research Station, Tamil Nadu Agricultural University, Tindivanam during January 2018 with the six different soaking treatments viz., soaking of single pods for $5 \mathrm{hrs}, 10 \mathrm{hrs}, 15 \mathrm{hrs}, 20 \mathrm{hrs}$, sowing of dry pods as such and kernel sowing as control in two varieties TMV 13 and VRI 7. From the above treatments irrespective of varieties, the results of $20 \mathrm{hrs}$ soaked seeds is on par with kernel sowing in number of days to emergence ( 5 days), days to initial ( 26 days)and $50 \%$ flowering ( 33.5 days) flowering and in all yield parameters including No. of pegs/plant (32.7 for kernel sowing and 31.8 for 20 hrs soaked pods), No. of pods/ plant (27.3 for kernel sowing and 26.7 for $20 \mathrm{hrs}$ soaked pods), 100 seed weight (45.3 for kernel sowing and 45.0 for 20 hrs soaked pods) and seed yield/ha (1904 for kernel sowing and 1858 for 20 hrs soaked pods).
\end{abstract}

Keywords: Groundnut, pod sowing, single pod, soaking of pods, whole pod sowing

\section{Introduction}

Groundnut (Arachis hypogaea) is an important leguminous oilseed crop and generally called as poor man's nut. Groundnut seed contains 44 to $56 \%$ oil and 22 to $30 \%$ protein on dry seed basis and is a rich source of minerals (P, Ca, mg and $\mathrm{K}$ ) and vitamins (James et al., 2014) ${ }^{[8]}$. It is also called as peanut, monkey nut and goober nut. It is a unique crop, matching the attributes for both legume and oilseed crop. Groundnut is one of the principal economic plants as a resource for edible oil and protein. It is the world's 13th most important food crop, 4th most important source of edible oil and 3rd most important source of vegetable protein. In single groundnut plant at least there will be $4-5$ single pods. In one hectare $250-300 \mathrm{~kg}$ of single pods could be separated. These single pods will escape in all types of decorticators and collected as such along with shelled seeds. Those single pods has to be collected separately and it should be unshelled manually i.e. by traditional method (pressing it in between thumb and finger). The above said process requires more labour and cost. As there will be more demand for this seed during seasons all the farmers and stakeholders are indeed to unshell the single pods manually and use it wisely to overcome the short fall in seed requirement. One more necessary for proposing the project is during breeder production the single pod will be rejected as it is missing some genetic characters like pod constriction, Pod reticulation (venation, ribbing, ridging) on the shell are the prominent Visual characteristic exhibited differently by groundnut cultivars. Hence the single pods will not fit into the above said genetic characters and their by the single pods will be rejected automatically. Hence with the aim of reducing the labour and cost and also effectively utilise the single pods produced, those single pods are sown as such in the field. Pod-sowing is an important technology in peanut cultivation and is widely used in southern and northern China (Yu, 2004; Chen et al., 2009; Chang et al., 2013) ${ }^{[14,5,3]}$. In the peanut producing areas of north China, there are droughts in spring, making it difficult for peanuts to germinate in the suitable season. If farmers wait for a spring rain, then they miss the best time for peanut cultivation. However, the use of pod-sowing and mulching film technology alleviates issues of low temperature and drought, conditions that are not suitable for planting ( $\mathrm{Fu}, 2009 ; \mathrm{Na}, 2010)^{[6,10]}$. In the peanut producing areas of south China, it is cold and rainy in spring, resulting in peanut seeds becoming mildewed and rotting in the soil, which reduces peanut yield significantly. 


\section{Materials and Methods}

The freshly harvested groundnut pods (both single \& double pods) were collected from Oilseeds Research Station, Tindivanam formed the base material for study. The field experiment was conducted during January 2018 at Oilseeds Research Station, TNAU, Tindivanam, Tamil Nadu with two varieties TMV 13 and VRI 7 as main plot treatment and six treatments as sub plot treatment viz., T1 - Kernel sowing (Conventional method); T2 - Sowing single pods (Dry); T3 Sowing of $5 \mathrm{hrs}$ water soaked single pods in 1:2 ratio; T4 Sowing of $10 \mathrm{hrs}$ water soaked single pods in 1:2 ratio; T5Sowing of $15 \mathrm{hrs}$ water soaked single pods in 1:2 ratio; T6 Sowing of $20 \mathrm{hrs}$ water soaked single pods in 1:2 ratio in Split plot techniques with three replication and $30 \times 10 \mathrm{~cm}$ as spacing. Ten plants from each plot were selected at random to record the following plant growth parameters like Plant population, Days to first and $50 \%$ flowering, Peg to pod per cent, Percentage of single seeded pods plant ${ }^{-1}$, Number of sound matured pods plant ${ }^{-1}$, Number of immature pods plant ${ }^{-1}$, Hundred kernel weight, Shelling percentage and Seed yield $\mathrm{ha}^{-1}$. The Growth, yield attributes and yield was subjected to ANOVA for statistical significance (Panse and Sukhtame, 1967) ${ }^{[12]}$.
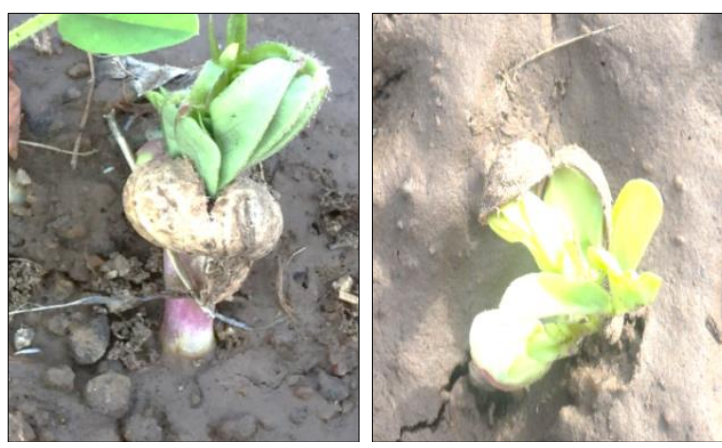

Fig 1: Germination of single pod sown in the field

\section{Results and Discussion}

The initial plant population was highest at kernel sowing $\left(637.2 / 20 \mathrm{~m}^{2}\right)$ followed by $20 \mathrm{hrs}$ soaked pods and very low at sowing the dry pods as such $\left(623.7 / 20 \mathrm{~m}^{2}\right)$. Among the varieties, TMV 13 and VRI 7 are performed equally in case of initial plant stand and days to initial flowering (Table.1.). This is mainly due to soaking effect. The result was in accordance with [Mudasir et al., 2012] [9], who reported that soaking the seeds in water improved the germination compared to control due to various factors such as softening of the seed coat, enzyme activation and swelling. Imbibition, the first phase of germination was found to be improved after soaking with water. The days to initial and fifty percent flowering was very minimum in kernel sowing and 20 hrs soaked pods (24 days for initial flowering and 33 days for $50 \%$ flowering), this is due to difference in days to emergence of kernels and other soaked pods. The beneficial effects of pre-sowing invigouration seed treatment have been primarily attributed to an advancement of germination process and flowering (Austin et al., 1969; Hydecker, 1974) ${ }^{[1,7]}$ and improvement in other seed quality traits. The number of pegs/plant was also highest at kernel sowing (35.7) which was onpar with 20 hrs soaked pods. Similar trend of results was observed in case of number of pods/plant as well as peg to pod ratio (Table.2.) Chatterjee et al. [1982] ${ }^{[4]}$ reported that the groundnut crop raised from seed kernels treated with water had appreciably higher number of pods per plant and higher 100 seed weight of kernels. Similarly, Basra et al. [2003] ${ }^{[2]}$ in canola and Rashid et al. [2004] ${ }^{[13]}$ in mungbean reported that primed seed plants produced more grains per pod. The number of mature pods/plant are highest at kernel sowing (23.8) which was onpar with $20 \mathrm{hrs}$ soaked pods (22.8) and in controversy, immature pods are very minimum in kernel sowing and $20 \mathrm{hrs}$ soaked pods (Table.3.). One more interesting fact is the number single pods produced also minimum in kernel sowing and $20 \mathrm{hrs}$ soaked pods. This is mainly due to factor of water deficit, which plays major role formation of single pods. Similarly, the shelling percentage is also higher in kernel sowing and $20 \mathrm{hrs}$ soaked pods, this is due to factor of production of fully matured and sound kernels higher in the above said two treatments.

Table 1: Effect of single pod sowing treatments on Plant Population, Days to initial and 50\% flowering in Groundnut cultivars

\begin{tabular}{|c|c|c|c|c|c|c|c|c|c|}
\hline \multirow{2}{*}{ Treatment/Varieties } & \multicolumn{3}{|c|}{ Initial Plant Population/20m } & \multicolumn{2}{c|}{ Days to initial flowering } & \multicolumn{3}{c|}{ Days to 50\% flowering } \\
\cline { 2 - 10 } & TMV 13 & VRI 7 & Mean & TMV 13 & VRI 7 & Mean & TMV 13 & VRI 7 & Mean \\
\hline Kernel sowing & 639.0 & 635.3 & 637.2 & 24.3 & 24.3 & 24.3 & 33.3 & 33.7 & 33.5 \\
\hline Dry pod sowing & 623.3 & 624.0 & 623.7 & 28.3 & 28.7 & 28.5 & 37.3 & 37.3 & 37.3 \\
\hline 5 hrs soaked pod & 625.7 & 626.0 & 625.8 & 26.7 & 27.3 & 27.0 & 36.0 & 35.3 & 35.7 \\
\hline 10 hrs soaked pod & 631.3 & 631.7 & 631.5 & 27.3 & 26.7 & 27.0 & 35.3 & 35.7 & 35.5 \\
\hline 15 hrs soaked pod & 631.7 & 633.3 & 632.5 & 26.7 & 26.3 & 26.5 & 34.7 & 34.3 & 34.5 \\
\hline 20 hrs soaked pod & 633.3 & 634.0 & 633.7 & 24.7 & 24.7 & 24.7 & 33.7 & 33.3 & 33.5 \\
\hline Mean & 630.7 & 630.7 & 630.7 & 26.3 & 26.3 & 26.3 & 35.1 & 34.9 & 35.0 \\
\hline & $\mathbf{V}$ & $\mathbf{T}$ & $\mathbf{V x T}$ & $\mathbf{V}$ & $\mathbf{T}$ & $\mathbf{V x T}$ & $\mathbf{V}$ & $\mathbf{T}$ & VxT \\
\hline S.Ed & 2.009 & 2.525 & 4.689 & 0.167 & 0.325 & 0.553 & 0.056 & 0.310 & 0.495 \\
\hline C.D(0.05) & 8.645 & 5.266 & 12.644 & 0.717 & 0.678 & 1.320 & 0.239 & 0.647 & 1.054 \\
\hline
\end{tabular}

Table 2: Effect of single pod sowing treatments on No. of pegs/plant, No. of pods/plant and Peg to Pod ratio in Groundnut cultivars.

\begin{tabular}{|c|c|c|c|c|c|c|c|c|c|}
\hline \multirow{2}{*}{ Treatment/Varieties } & \multicolumn{3}{|c|}{ No. of pegs/plant } & \multicolumn{3}{|c|}{ No. of pods/plant } & \multicolumn{3}{|c|}{ Peg to Pod ratio } \\
\hline & TMV 13 & VRI 7 & Mean & TMV 13 & VRI 7 & Mean & TMV 13 & VRI 7 & Mean \\
\hline Kernel sowing & 36.0 & 35.3 & 35.7 & 27.7 & 26.7 & 27.2 & 76.9 & 75.6 & 76.3 \\
\hline Dry pod sowing & 33.0 & 32.7 & 32.8 & 24.3 & 23.7 & 24.0 & 73.7 & 72.5 & 73.1 \\
\hline 5 hrs soaked pod & 33.3 & 32.7 & 33.0 & 24.7 & 24.3 & 24.5 & 73.8 & 74.4 & 74.1 \\
\hline 10 hrs soaked pod & 34.0 & 33.0 & 33.5 & 24.7 & 24.7 & 24.7 & 72.6 & 74.7 & 73.7 \\
\hline 15 hrs soaked pod & 34.3 & 34.0 & 34.2 & 26.0 & 26.0 & 26.0 & 75.7 & 76.4 & 76.0 \\
\hline 20 hrs soaked pod & 35.3 & 35.0 & 35.2 & 27.3 & 26.0 & 26.7 & 77.3 & 74.5 & 75.9 \\
\hline Mean & 34.3 & 33.8 & 34.1 & 25.8 & 25.2 & 25.5 & 75.0 & 74.7 & 74.9 \\
\hline & $\mathrm{V}$ & $\mathrm{T}$ & VxT & $\mathrm{V}$ & $\mathrm{T}$ & VxT & $\mathrm{V}$ & $\mathrm{T}$ & VxT \\
\hline
\end{tabular}




\begin{tabular}{|c|c|c|c|c|c|c|c|c|c|}
\hline S.Ed & 0.709 & 0.818 & 1.558 & 0.696 & 0.967 & 1.751 & 0.714 & 2.185 & 3.564 \\
\hline C.D $(0.05)$ & 3.052 & 1.706 & 4.323 & 2.995 & 2.017 & 4.572 & 3.071 & 4.558 & 7.910 \\
\hline
\end{tabular}

Table 3: Effect of single pod sowing treatments on No. of Mature pods/plant, No. of Immature pods/plant, Percentage of single pods/plant and100 seed weight in Groundnut cultivars.

\begin{tabular}{|c|c|c|c|c|c|c|c|c|c|c|c|c|}
\hline \multirow{2}{*}{ Treatment / Varieties } & \multicolumn{3}{|c|}{ No. of Mature pods/plant } & \multicolumn{3}{|c|}{ No. of Immature pods/plant } & \multicolumn{3}{|c|}{ Percentage of single pods/plant } & \multicolumn{3}{|c|}{100 seed weight } \\
\hline & TMV 13 & VRI 7 & Mean & TMV 13 & VRI 7 & Mean & TMV 13 & VRI 7 & Mean & TMV 13 & VRI 7 & Mean \\
\hline Kernel sowing & 24.3 & 23.3 & 23.8 & 3.7 & 3.3 & 3.5 & 23.8 & 10.0 & 16.9 & 44.2 & 46.3 & 45.3 \\
\hline Dry pod sowing & 19.0 & 18.7 & 18.8 & 5.3 & 5.0 & 5.2 & 35.7 & 15.6 & 25.7 & 43.8 & 45.7 & 44.8 \\
\hline 5 hrs soaked pod & 19.7 & 19.7 & 19.7 & 5.0 & 4.7 & 4.8 & 33.0 & 13.6 & 23.3 & 43.9 & 45.3 & 44.6 \\
\hline $10 \mathrm{hrs}$ soaked pod & 20.0 & 20.3 & 20.2 & 4.7 & 4.3 & 4.5 & 32.5 & 12.3 & 22.4 & 43.6 & 45.8 & 44.7 \\
\hline $15 \mathrm{hrs}$ soaked pod & 21.7 & 21.7 & 21.7 & 4.3 & 4.3 & 4.3 & 28.4 & 13.5 & 20.9 & 43.8 & 46.0 & 44.9 \\
\hline $20 \mathrm{hrs}$ soaked pod & 23.3 & 22.3 & 22.8 & 4.0 & 3.7 & 3.8 & 28.0 & 11.6 & 19.8 & 44.0 & 46.0 & 45.0 \\
\hline Mean & 21.3 & 21.0 & 21.2 & 4.5 & 4.2 & 4.4 & 30.3 & 12.8 & 21.5 & 43.9 & 45.9 & 44.9 \\
\hline & V & $\mathrm{T}$ & VxT & $\mathrm{V}$ & $\mathrm{T}$ & VxT & $\mathrm{V}$ & $\mathrm{T}$ & VxT & $\mathrm{V}$ & $\mathrm{T}$ & VxT \\
\hline S.Ed & 0.694 & 0.775 & 1.491 & 0.294 & 0.413 & 0.745 & 1.872 & 1.938 & 3.827 & 0.172 & 0.241 & 0.436 \\
\hline C.D(0.05) & 2.986 & 1.616 & 4.184 & 1.265 & 0.861 & 1.940 & 8.053 & 4.043 & 11.027 & 0.741 & 0.503 & 1.136 \\
\hline
\end{tabular}

Table 4: Effect of single pod sowing treatments on shelling percentage and seed yield in Groundnut cultivars.

\begin{tabular}{|c|c|c|c|c|c|c|c|c|c|}
\hline \multirow{2}{*}{ Treatment / Varieties } & \multicolumn{3}{|c|}{ Shelling percentage } & \multicolumn{2}{c|}{ Seed Yield /plot (kg) } & \multicolumn{3}{c|}{ Seed Yield (kg/ha) } \\
\cline { 2 - 10 } & TMV 13 & VRI 7 & Mean & TMV 13 & VRI 7 & Mean & TMV 13 & VRI 7 & Mean \\
\hline Kernel sowing & 71.9 & 72.6 & 72.3 & 4.27 & 3.35 & 3.81 & 2133 & 1675 & 1904 \\
\hline Dry pod sowing & 71.3 & 72.5 & 71.9 & 3.35 & 3.00 & 3.18 & 1675 & 1500 & 1588 \\
\hline 5 hrs soaked pod & 71.6 & 72.2 & 71.9 & 3.47 & 3.07 & 3.27 & 1733 & 1533 & 1633 \\
\hline 10 hrs soaked pod & 71.8 & 72.4 & 72.1 & 3.62 & 3.10 & 3.36 & 1808 & 1550 & 1679 \\
\hline 15 hrs soaked pod & 71.9 & 72.4 & 72.2 & 3.83 & 3.18 & 3.51 & 1917 & 1592 & 1754 \\
\hline 20 hrs soaked pod & 71.5 & 72.6 & 72.1 & 4.10 & 3.33 & 3.72 & 2050 & 1667 & 1858 \\
\hline Mean & 71.7 & 72.5 & 72.1 & 3.77 & 3.17 & 3.47 & 1886 & 1586 & 1736 \\
\hline & V & T & VxT & V & T & VxT & V & T & VxT \\
\hline S.Ed & 0.106 & 0.278 & 0.458 & 0.049 & 0.057 & 0.108 & 24.414 & 28.585 & 54.193 \\
\hline C.D(0.05) & 0.456 & 0.580 & 1.038 & 0.210 & 0.119 & 0.299 & 105.047 & 59.628 & 149.617 \\
\hline
\end{tabular}

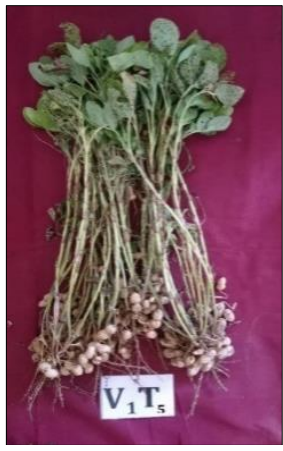

$\mathbf{T}_{1}$ - Kernels from doble pod;

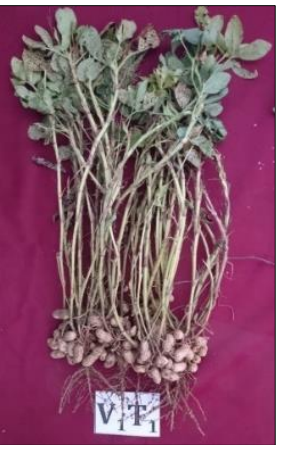

Fig 2: Comparison of best treatment with control
Finally, the above mentioned factors paved the way for improved yield interms of kilogram/plot as well as yield/ha. The highest yield was recorded in Kernel sowing and $20 \mathrm{hrs}$ soaked pods $1904 \mathrm{~kg}$ and $1858 \mathrm{~kg}$ respectively). And among the varieties TMV 13 performed better by registering highest yield of $1886 \mathrm{~kg}$ while VRI 7 registered $1586 \mathrm{~kg}$ of yield. The results are in accordance with the results obtained by Narayanareddy and Biradarpatil, (2012) in sunflower.

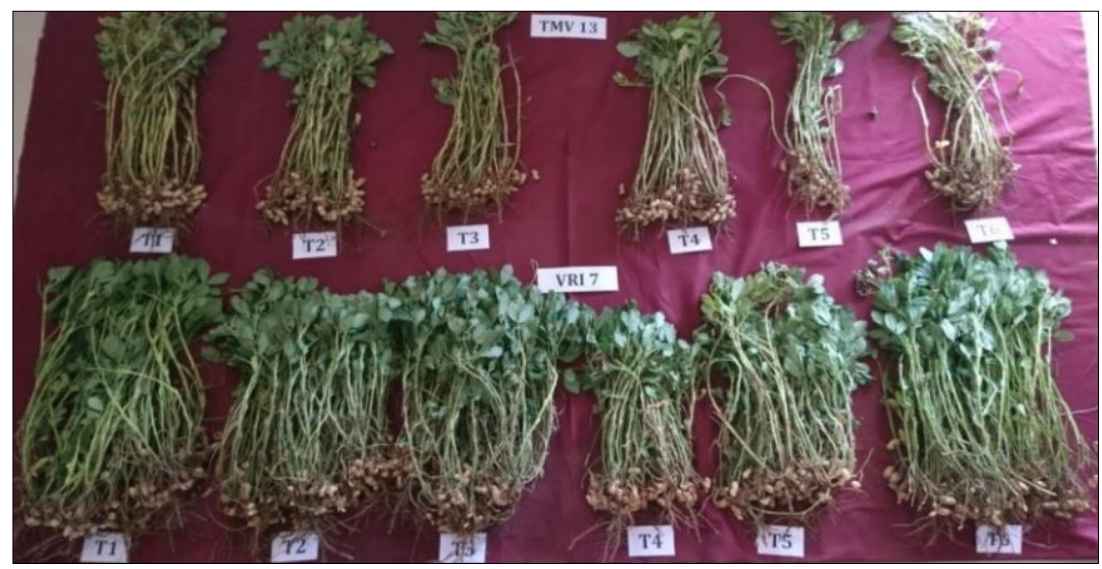

Fig 3: Single plant yield of all the treatments taken for the study 2509 


\section{Conclusions}

Irrespective of varieties, the pods soaked for $20 \mathrm{hrs}$ registered maximum emergence percent, reduced flowering days, and maximum yield and yield attributing characters and its performance is similar to kernel sowing irrespective of all the observations. Sowing of dry pods also recorded good yield but comparatively lower than kernel sowing and $20 \mathrm{hrs}$ soaked seeds.

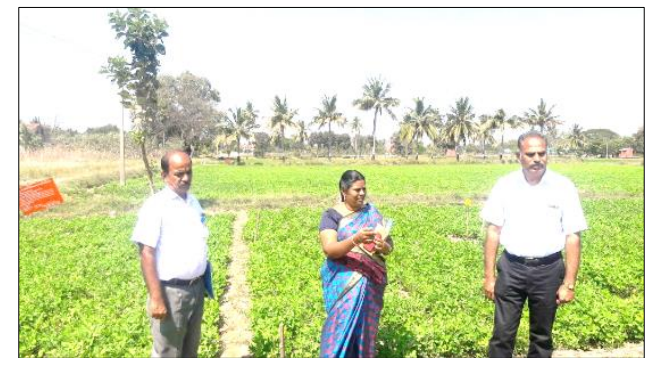

Fig 4: Field view

\section{References}

1. Austin RB, Longden PC, Hutchinson J. Some effects of hardening carrot seeds, Ann. Bot 1969;33:883-895.

2. Basra SMA, Ehsanullah EA, Warraich MA, Afzal I. Effect of storage on growth and yield of primed canola (Brassica napus) seeds. Int. J Agri. Bio 2003;5:117-120.

3. Chang M, Zheng Y. Effects of coated peanut sowing on germination of peanut's seedlings. Journal of Anhui Agricultural. Science 2013;41:505-506. [In Chinese.]

4. Chatterjee BN, Ghosh RK, Dasgupta B. Effect of presowing seed treatment on productivity of groundnut. J Oilseeds Res 1982;2:246-254.

5. Chen Z, Zou X, Song L. The study on peanut pod sowing technique. Acta Agriculturae Jiangxi 2009;2:34-35. [In Chinese.]

6. $\mathrm{Fu} \mathrm{X}$. The seeding technique of peanut with peanut shell in northern China. Rain Fed Crops 2009;29:38-39. [In Chinese.]

7. Heydecker W. Germination of an idea: the priming of seeds, Rep.1973, Univ. Nottingham School Agric 1974;III:50-67.

8. James Seutra Kaba F, Kumaga K, Kwadwo Ofori. Effect of flower production and time of flowering on pod yield of peanut (Arachis hypogaea L.). Journal Agricultural and Veterinary Science 2014;7:44-49.

9. Mudasir Q, Fatima K, Haukat SK. Indian J. Appl. Pure Biol 2012;27(1):105-108.

10. Na Y. Preliminary report on early sowing of shell-peanut covered with plastic film in Shenyang. Ra in Fed Crops 2010;30:431-433. [In Chinese.]

11. Narayanareddy AB, Biradarpatil NK. Effect of presowing invigouration seed treatments on seed quality and crop establishment in sunflower hybrid KBSH-1. Karnataka J. Agric. Sci 2012;25(1):43-46.

12. Panse VG, Sukhatme PV. Statistical methods for agricultural workers 1985, 97-164.

13. Rashid A, Harris D, Hollington P, Ali S. On-farm seed priming reduces yield losses of mung bean (Vigna radiata) associated with mung bean yellow mosaic virus in NWFP of Pakistan. Crop Protect 2004;23:1119-1124.

14. Yu W. Study on the yield increasing mechanism of peanut Pod-sowing and film mulching cultivation. Crops 2004;6:20-21. [In Chinese.] 